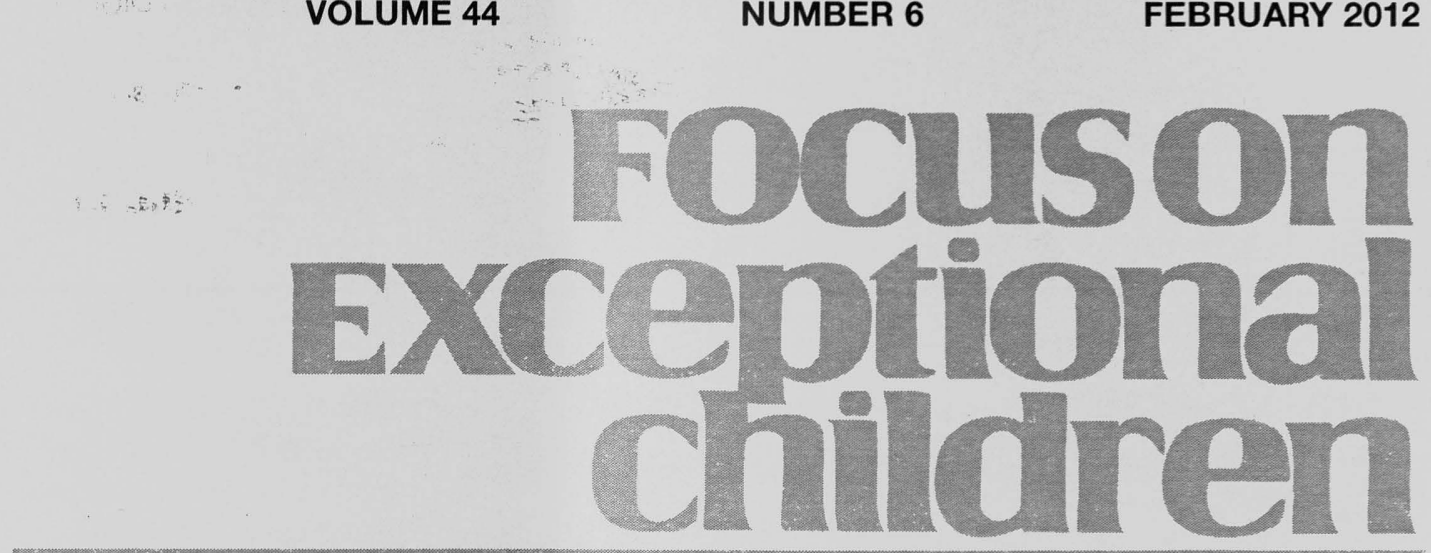

\title{
Supporting Paraeducators through a Collaborative Classroom Support Plan
}

\author{
Andrea M. Capizzi and M. Alexandra Da Fonte
}

\begin{abstract}
Ms. Simmons was eager to start her first year of teaching. Last spring, she student taught in a special education resource classroom and was able to work with students with a range of disabilities in a variety of settings. Her mentor teacher Mrs. Jones was quite experienced and made everything look so easy. Mrs. Jones showed Ms. Simmons how she managed student schedules, provided individualized and group instruction, and supported students in the general education setting. Ms. Simmons was even able to work with Ms. Tully, the classroom paraeducator who had worked with Mrs. Jones for 5 years. Overall, Ms. Simmons felt thoroughly prepared for her new role as a special educator working with a caseload of 20 students with disabilities ranging from moderate learning and behavioral disabilities to autism and multiple disabilities; that is, until she learned that she would also have to supervise and manage three paraeducators, one who had vastly more experience working with students than she and two who were brand new to the position. She didn't know where to begin and asked herself, "How can I, a new teacher, guide and support my paraeducators?"
\end{abstract}

Paraeducators, also known as teacher aides, paraprofessionals, and educational or instructional assistants, have become increasingly vital participants in school communities. They provide support in many capacities in schools. Their roles may include working one-on-one with students in the classroom and supporting teachers and students throughout the day in varying activities. Some common activities are delivering lessons, supporting self-care, creating materials, collecting data, managing behavior, supervising the lunchroom, helping out in the library, or even riding the bus with students (Ashbaker \& Morgan, 2006; May \& Marozas, 1981). Although paraeducators are expected to complete these various tasks, they receive little or no training prior to starting their positions. In addition, the teachers who supervise paraeducators are often unprepared or untrained to work with or provide paraeducators needed training once they begin their work in the school setting.

Dr. Capizzi is an assistant professor of the practice in the Department of Special Education at Vanderbilt University. Dr. Da Fonte is an assistant professor of the practice in the Department of Special Education at Vanderbilt University. 


\section{THE NUMBERS}

It is difficult to specify the number of paraeducators working in $\mathrm{K}-12$ schools in the United States. Estimates range from 500,000 to 1.3 million (Pickett, Likins, \& Wallace, 2003; U.S. Department of Labor, 2010). According to the most recent data available from U.S. Department of Labor, in 2008, there were approximately 1.1 million paraeducators working in "Educational Services." That includes both public and private schools in part- or full-time positions with students in school settings (2010). The National Resource Center on Paraeducators conducted a survey of state education associations for the 1999-2000 school year in an attempt to more clearly identify the number of paraeducators and their roles in schools (Pickett et al., 2003). They found that information was not readily available for nonTitle 1 schools. Through their survey, they identified more than 525,000 paraeducators in full-time positions, with approximately 290,000 working in special educationrelated capacities. This was likely an underestimate of the

\section{Focuson
Exceptional
children}

ISSN $0015-511 \mathrm{X}$

FOCUS ON EXCEPTIONAL CHILDREN (USPS 203-360) is published monthly except June, July, and August as a service to teachers, special educators, curriculum specialists, administrators, and those concerned with the special education of exceptional children. This publication is annotated and indexed by the ERIC Clearinghouse on Handicapped and Gifted Children for publication in the monthly Current Index to Journals in Education (CIJE) and the quarterly index, Exceptional Children Education Resources (ECER). The full text of Focus on Exceptional Children is also available in the electronic versions of the Education Index. It is also available in microfilm from Serials Acquisitions, National Archive Publishing Company, P.O. Box 998, Ann Arbor, MI 481 06-0998. Subscription rates: individual, \$50 per year; institutions, \$68 per year. Copyright (C) 2012, Love Publishing Company. All rights reserved. Reproduction in whole or part without written permission is prohibited. Printed in the United States of America. Periodical postage is paid at Denver, Colorado. POSTMASTER: Send address changes to:

\section{Love Publishing Company \\ Executive and Editorial Office P.O. Box 22353 \\ Denver, Colorado 80222 \\ Telephone (303) 221-7333}

\section{CONSULTING EDITORS}

Steve Graham

Vanderbilt University
Ron Nelson

University of Nebraska-Lincoln

Eva Horn

University of Kansas

Carrie E. Watterson

Senior Editor
Stanley F. Love

Publisher true number because of challenges related to collecting information with their survey methods, such as a lack of centralized information regarding counts of paraeducators at the district and state levels.

Regardless of the counts of paraeducators working in schools at this time, their numbers are projected to grow. The Bureau of Labor Statistics has projected a $10 \%$ growth in jobs for paraeducators between 2008 and 2018 (U.S. Department of Labor, 2010). The increase in paraeducator support for students with disabilities in inclusive and more supportive settings demands that teachers, schools, and administrators work together to prepare paraeducators for their roles and responsibilities. The purpose of this article is to (a) identify the logistical challenges to supporting special education teachers and paraeducators working with students with exceptionalities, (b) provide specific strategies and methods to support and guide special education teachers and paraeducators, and (c) offer suggestions for working through common problems experienced by collaborative teacher-paraeducator team members.

\section{TRAINING CHALLENGES}

Despite a movement towards a certification for paraeducators (Schmidt, Grenough, \& Nelson, 2002), few of these professionals have formal training prior to beginning their employment in the area or task in which they will be engaged (Carroll, 2001; Downing, Ryndak, \& Clark, 2000; Wadsworth \& Knight, 1996). Most paraeducators come to the job with little or no education beyond a high school diploma, underqualified and unprepared for the responsibilities of working with students with exceptionalities (Morgan, Ashbaker, \& Forbush, 1998; Wadsworth \& Knight, 1996). Lack of training leads paraeducators to question their capabilities and feel unprepared for their roles in the classroom (Downing et al., 2000). Furthermore, limited supervision and feedback once they are in practice can lead paraeducators to feel isolated and unsure (Marks, Schrader, \& Levine, 1999).

There is often little time for training prior to "throwing" a paraeducator into the classroom. On-the-job training is a particular challenge. Many districts do not have the funds to compensate paraeducators for training before and during their employment. Therefore, much of the training is done "on the fly," if at all. Paraeducators report that their training is often little more than observing teachers and other paraeducators as they work with students, supplemented with a brief explanation prior to undertaking tasks (Carroll, 2001). Hectic student and classroom schedules and heavy responsibilities held by classroom teachers limit the time available for training.

Unfortunately, poorly prepared teachers offer another challenge to training, guiding, and equipping paraeducators 
with tools they need to effectively perform their duties in the school. General and special education teachers are often ill prepared for supervisory and training roles. Very few states include teacher-credentialing standards covering competency in managing, training, and supporting paraeducators (Wallace, Shin, Bartholomay, \& Stahl, 2001). Teacher preparation programs provide limited or no training on how to work effectively with paraeducators (Drecktrah, 2000; Wallace et al., 2001); therefore, new teachers like Ms. Simmons in our opening vignette often do not have the skills to manage paraeducators assigned to their students or programs. Furthermore, despite the lack of preservice training for teachers, school districts rarely respond with in-service training for teachers on managing and working with paraeducators. This forces teachers to learn to manage paraeducators on their own (Drecktrah, 2000). In effect, both teacher and paraeducator are learning together, on the job, without guidance.

\section{THE CHARGE TO PROVIDE TRAINING}

Responsibility for using evidence-based practices in special education does not lie only with teachers. Paraeducators should be trained to use and deliver evidence-based support to students on the tasks they need to perform, and they should be provided adequate support and ongoing supervision (Doyle, 2008; French, 2003b). Despite a lack of sufficient training, paraeducators are still expected to provide effective support to students. Increased dependence on paraeducators to work with students with disabilities in both general and in more supportive educational settings requires quality training of paraeducators in fundamental strategies to enhance outcomes for students with exceptionalities. This is vitally important because the paraeducator is, at times, the primary person involved with core planning, informal assessment and daily data collection, adaptations, and instructional decisions for students (Downing et al., 2000; Giangreco, Broer, \& Edelman, 2002; Giangreco, Edelman, \& Broer, 2001).

IDEA 2004 stressed that "paraprofessionals and assistants who are appropriately trained and supervised ... be used to assist in the provision of special education and related services to children with disabilities" (20 U.S.C. 1412 (a)(14) (B) (iii)). For these reasons it is critical for administrators and teachers to collaborate in identifying how to ensure that paraeducators are provided with training and guidance needed to enhance their professional skills. Mutual respect and understanding among administrator, teacher, and paraeducator, as well as a clear plan for training, is essential to make certain all student needs are being met and planned for.

Collaboration and delegation are vital to effective teacherparaeducator partnerships. Collaboration can be defined as the agreement and development of shared goals, expectations, and directions between two or more people when sharing responsibilities to obtain the set goal (Bruner, 1991). Effective collaboration is based on involving all key members in the decision-making process. Additionally, members should have a shared vision for student goals and outcomes and open lines of communication (French, 2003a). Delegation, in contrast, is based on trusting an individual to complete a predetermined task or role and making this task the individual's responsibility (French, 2003a, 2003b). Supervising teachers are responsible for collaborating with paraeducators while also delegating tasks to them in the classroom or program. Delegation of a task does not release responsibility for this duty. As a leader, the teacher remains accountable for the completion of the task. But, at the same time, the responsibility when delegating shifts to ensure that support is provided at a level to allow the paraeducator to complete the task. Collaboration and delegation are more effective when the teacher has taken an active role to build a team that is based on trust, respect, and hard work.

The unfortunate lack of information and support provided to paraeducators, along with the value in developing an effective team, warrant the need to outline, identify, and understand the responsibilities each member has within a classroom setting. For a collaborative team to succeed, one must always take into account that everyone has his or her own individual way of working. This will increase the understanding that no two people work following the exact same structure. As a result, we developed the Collaborative Classroom Support Plan (CCSP), a systematic tool for administrators and teachers to use to identify core duties and skills of team members, share information, and more effectively prepare paraeducators for their responsibilities.

\section{THE COLLABORATIVE CLASSROOM SUPPORT PLAN (CCSP)}

The CCSP was designed with the principles of collaboration and delegation in mind. It is one way to encourage open communication and sharing of information while specifying responsibilities. It was developed to support exceptional educators in creating positive and collaborative environments with paraeducators to benefit students within the educational setting. The goal of the CCSP is for all team members to understand the importance of collaboration and to increase teamwork. After completion and review of the CCSP, each team member should better understand his or her role and feel valued as a member of the team. Additionally, the CCSP offers the opportunity to create an open discussion of work ethics, expectations, personal styles of work, response to feedback, and opportunities to improve professional skills. The CCSP focuses on four general components (see Figure 1) that should provide teachers and paraeducators a means 


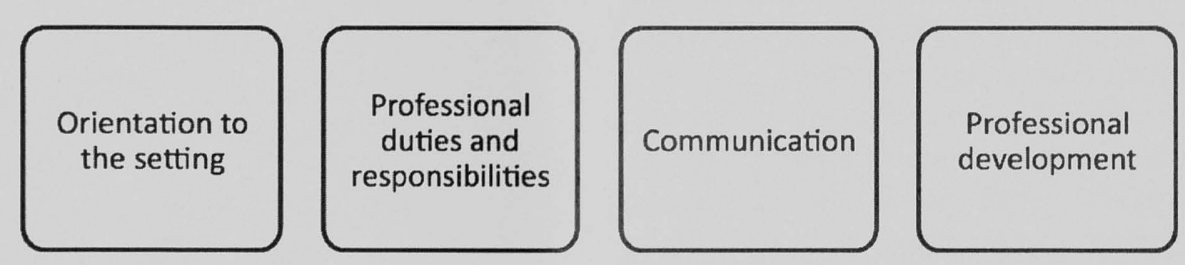

FIGURE 1.

The Collaborative Classroom Support Plan

to build a collaborative setting. All components have equal value and should be organized to best meet the needs of the setting. The components of the CCSP are

1. orientation to the setting,

2. professional duties and responsibilities,

3. communication, and

4. professional development.

A collaborative environment is not easy to achieve. Novice teachers, who frequently encounter veteran paraeducators or come across paraeducators who are not open to accepting or acknowledging a new supervising teacher or strategies, tend to find this especially challenging. This frequently creates a negative atmosphere within the environment, making it difficult for novice teachers specifically because of their lack of training and experience in working with paraeducators. For these and many other reasons, a plan designed to enhance a collaborative education environment is vital in any school setting. We provide a rationale for each of the components and explain how to use the CCSP as a tool to enhance communication and collaborative teamwork among teacher-paraeducator teams. We suggest collecting the components of the CCSP in a manual (see Figures 2-6) that can be individualized to suit the needs of a particular classroom, teacher, and/or paraeducator.

\section{Orientation to the setting}

Many paraeducators are not provided training or an orientation to the educational setting prior to beginning their new position (Giangreco, Edelman, \& Broer, 2003). An orientation to their new work setting is integral to making a paraeducator feel welcome. Familiarizing a paraeducator with a school not only facilitates efficient and effective work within the school setting but also makes the paraeducator feel like a valued part of the school staff. Preservice training should be provided before paraeducators begin working with students in the hope of increasing the paraeducator's confidence in his or her ability to perform job duties (Trautman, 2004).
A thorough orientation also provides paraeducators with an opportunity to clearly understand school and classroom expectations and procedures. Orientation meetings should include introduction to key staff, tours of the setting, and detailing key policies. The orientation meeting may include the following:

- Identification of the supervising teacher

- Introduction to administrator(s) and other key school personnel (e.g., school secretary, librarian, nurse, occupational therapist, etc.)

- Tour of the school with a focus on places where the paraeducator will primarily work

- Location of other important areas (e.g., staff lounge, copy machines, staff restrooms, etc.)

- Explanation of appropriate dress for the setting

- Arrival and departure times

- Policies for reporting absences

- Procedures for fire, inclement weather, and other emergencies

Figure 7 illustrates the progression of information needed regarding orientation to the setting. The first section for the CCSP (see Figure 2) serves as a means to compile this information. Time spent on the orientation will make the paraeducator feel valued, informed, and welcomed, thereby setting the stage for collaboration. Paraeducators should be guided on outlining questions they may have about the setting and overall school policies so these can be addressed at this time.

\section{Professional Duties and Responsibilities}

Paraeducator roles vary significantly by district, school, and program (French, 1998; Giangreco et al., 2001). Their responsibilities may change from year to year or even midschool year, and teachers' perceptions of their roles may influence responsibilities. Some teachers see paraeducators as assistants to students, while others see them as assistants to the supervising teacher (French, 1998). Clear definition of one's role is critical for success in any job position. Carefully planning and clarifying the roles of paraeducators can help 


\section{Collaborative Classroom Support Plan}

School:

School year:

Classroom:

Supervising Teacher:

Paraeducator(s):

\section{Orientation to the Setting}

School Description:

Principal:

Assistant Principal(s):

Other School Personnel and Their Roles:

School Map: (add here)

School Policies:

- Attire:

- Arrival/Departure:

- Absence Reporting:

Emergency Procedures:

- Fire:

- Inclement Weather:

- Safety/Emergency Plan:

FIGURE 2.

CCSP: Orientation to the Setting

develop positive, effective working relationships (Malmgren, Causton-Theoharis, \& Trezek, 2005) among school faculty and staff. Paraeducators should be provided with clear information on their duties, responsibilities to the students, and responsibilities to the supervising teacher (French, 1999a, 1999b; Hilton \& Gerlach, 1997; Trautman, 2004). Discussion of role and responsibilities at the initial hire and orientation allows early communication and an opportunity to discuss questions and concerns and to provide additional clarification. 


\section{Professional Duties and Responsibilities}

Job Description:

- Supervising Teacher:

- Classroom/Educational Setting Description:

- Duties/Responsibilities:

(Your responsibilities will include the following, but you will likely be called on to complete additional tasks as needed)

List duties/responsibilities below and mark a $\checkmark$ underneath the person(s) responsible

\begin{tabular}{|l|l|l|l|}
\hline \multicolumn{1}{|c|}{ Duty } & $\begin{array}{c}\text { Teacher's } \\
\text { Responsibility }\end{array}$ & $\begin{array}{c}\text { Paraeducator's } \\
\text { Responsibility }\end{array}$ & $\begin{array}{c}\text { Shared } \\
\text { Responsibility }\end{array}$ \\
\hline Responsibilities to the School & & & \\
\hline & & & \\
\hline & & & \\
\hline & & & \\
\hline Responsibilities to the Classroom & & & \\
\hline & & & \\
\hline & & & \\
\hline Responsibilities to the Supervising Teacher & & & \\
\hline & & & \\
\hline & & & \\
\hline
\end{tabular}

Schedule:

(Your schedule is subject to change as student, school, and program needs change. Thanks for being flexible!)

\begin{tabular}{|l|l|l|}
\hline \multicolumn{3}{|c|}{ Daily Schedule } \\
\hline & Placement/Task & Time \\
\hline Work & & \\
\hline Breaks & & \\
\hline Lunch & & \\
\hline
\end{tabular}

FIGURE 3.

CCSP: Professional Duties and Responsibilities

Although paraeducator roles are quite varied (e.g., oneon-one vs. classroom support), there is an overall agreement and general understanding that paraeducator responsibilities are based on assisting in the provision, modification, and adaption of instruction for students with exceptional needs
(Giangreco et al., 2002). Paraeducators may spend their time reinforcing learning experiences and skills introduced by the teacher, modifying materials, providing one-on-one assistance to students as needed, and providing support in the data collection process. While it is quite helpful to take 


\section{Communication}

"If thoughts corrupt language, language can also corrupt thoughts" -George Orwell (1981)

Evening/weekend emergency contact information:

\author{
Supervising Teacher \\ Phone: \\ Email:
}

Paraeducator

Phone:

Email

Your primary contact regarding your position is This is whom

you should contact if you have questions or concerns about any aspect of your duties or responsibilities.

Each week, we will have a team meeting on (day of week) at (time).

At this meeting, please be prepared to discuss job responsibilities for the week, schedule changes, student needs and concerns, and new strategies.

\section{Confidentiality:}

- We work very hard to respect the privacy of our students and their families. Please remember that we do not discuss our students in areas where others can hear us. For this reason, do not discuss students in public areas such as the lounge, the office, the hallways, the library, or the lunchroom.

- If a teacher or other staff member asks you questions about a student regarding his/her family, home, or disability that is beyond the scope of what is needed to teach the child in the classroom, please do not discuss the student; instead, please refer that person to your Supervising Teacher.

- If a parent or guardian of another student asks you about a particular student who is not his/her own, please tell them that you are not at liberty to discuss that student and refer the parent or guardian to the Supervising Teacher.

preferred duties into consideration when assigning responsibilities to paraeducators (May \& Marozas, 1981), it is important to clarify that sometimes multiple paraeducators and the supervising teacher may share responsibilities. An example of the separation and blending of responsibilities between teacher and paraeducator is shown in Figure 8.

Delineation of professional duties and responsibilities should be addressed as soon as a paraeducator begins his or 


\section{People-First Language:}

$\otimes \quad$ When speaking or describing a student, always be sure to think about the person first.

$\otimes \quad$ Avoid using labels

\begin{tabular}{|l|l|}
\hline \multicolumn{1}{|c|}{ Nonexamples } & \multicolumn{1}{c|}{ Examples } \\
\hline Handicapped students/individuals & Students/individuals with disabilities \\
\hline She is learning disabled & She has learning disabilities \\
\hline She is autistic & She has autism \\
\hline
\end{tabular}

\section{Work style preference evaluation:}

\begin{tabular}{|c|c|c|}
\hline \multicolumn{3}{|c|}{ Write an $x$ on the line closer to the statement that best describes you } \\
\hline I like challenges & 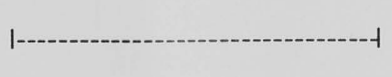 & $\begin{array}{l}\text { | prefer working on things I } \\
\text { know how to do }\end{array}$ \\
\hline I like working independently & 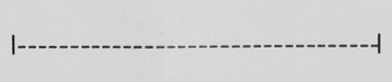 & $\begin{array}{l}\text { I like to know exactly what I } \\
\text { need to do }\end{array}$ \\
\hline I like a flexible schedule & 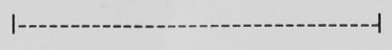 & I prefer a clear schedule \\
\hline $\begin{array}{l}\text { I am comfortable working in } \\
\text { other teacher's spaces }\end{array}$ & 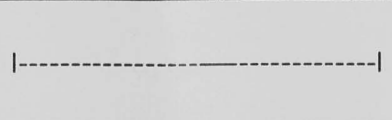 & $\begin{array}{l}\text { I like to have my own } \\
\text { personal space in the } \\
\text { classroom }\end{array}$ \\
\hline $\begin{array}{l}\text { I like discussing situations } \\
\text { when things don't go well }\end{array}$ & - & $\begin{array}{c}\text { I like to work things out on } \\
\text { my own when things don't go } \\
\text { well }\end{array}$ \\
\hline I am a "big picture" person & | & I like taking care of details \\
\hline $\begin{array}{l}\text { I like doing many things at } \\
\text { once }\end{array}$ & |---_- & $\begin{array}{l}\text { I like doing one thing at a } \\
\text { time }\end{array}$ \\
\hline I am an energetic person & | & I am a calm person \\
\hline
\end{tabular}

FIGURE 5.

CCSP: Work Styles Preference

her position. Clear and comprehensive information on tasks, roles, and responsibilities within the setting (i.e., characteristics, knowledge, skills) is vitally important for the completion of the job requirements (Dierdorff \& Morgeson,
2007). The CCSP provides a section where this can be clarified for paraeducators and teachers (see Figure 3). Identification of the supervising role and a clear description of the educational work setting are good places to start when 


\section{Professional Development}

I would like to learn more about:

Disability characteristics
Instructional strategies
Behavior management
Healthcare management
Data collection and data management
$\quad$ Creating and adapting instructional materials
$\quad$ Other __

District-Level Professional Development Opportunities:

SchootLevel Professional Development Opportunities:

Tip sheets:

(Develop and attach tip sheets for evidence-based skills needed in your setting)

FIGURE 6.

CCSP: Professional Development

explaining job duties. Next, it is important to describe and specify the educational setting or settings in which the paraeducator may work. Primary work in a resource room is quite different than in the general education inclusive classroom or even in a self-contained setting. The CCSP offers a section where the type of setting can be listed and the person responsible can be noted. The list provided in the CCSP may not include everything a paraeducator is expected to do, and paraeducators should be fully informed that, like other professionals in the school, they will likely be called upon to 


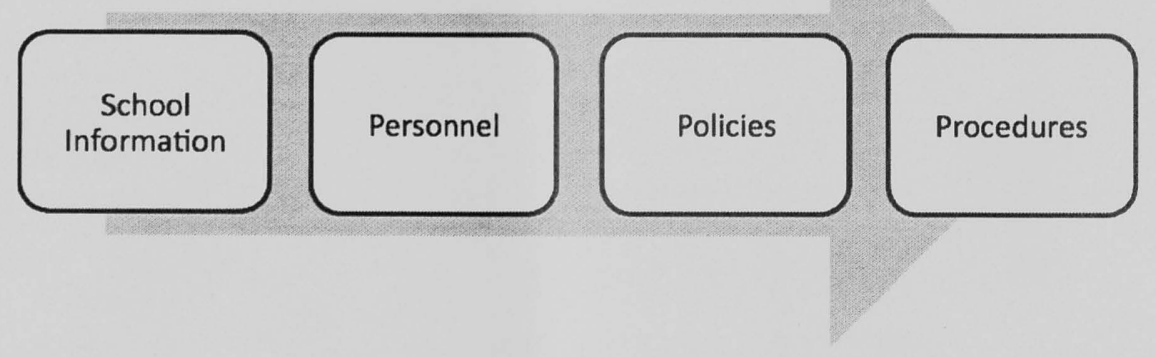

FIGURE 7.

Progression of Setting Orientation Information

complete additional tasks as student and school needs arise. Duties and responsibilities to the school, classroom, and supervising teacher should be clearly outlined and identified to improve communication and decrease confusion about personal versus team responsibilities.

\section{Daily Schedule}

Managing paraeducator schedules can be particularly challenging and a source of confusion. Paraeducators often follow their students and move around the school building during the day. Consequently, their lunch and break schedules are often at times other than that of the supervising teacher so that there is always someone available to be with students. These highly orchestrated schedules can be rather confusing. Hence, it is important to provide paraeducators with their schedule as well as the schedule of the supervising teacher to ensure that everyone is aware of each other's location during the day. There is a section on the CCSP devoted to providing specific information about work, break, and lunch schedules (see Figure 3). Additionally, schedule information should be detailed enough to so that paraeducators feel fully informed and aware of their daily activities.

\section{Communication}

Effective communication is essential when working as part of a team. In the context of teacher-paraeducator teams, communication is complex and includes various components such as collaboration strategies, training, meetings, providing feedback, and understanding individual work styles. The multifaceted components of communication are represented in Figure 9.

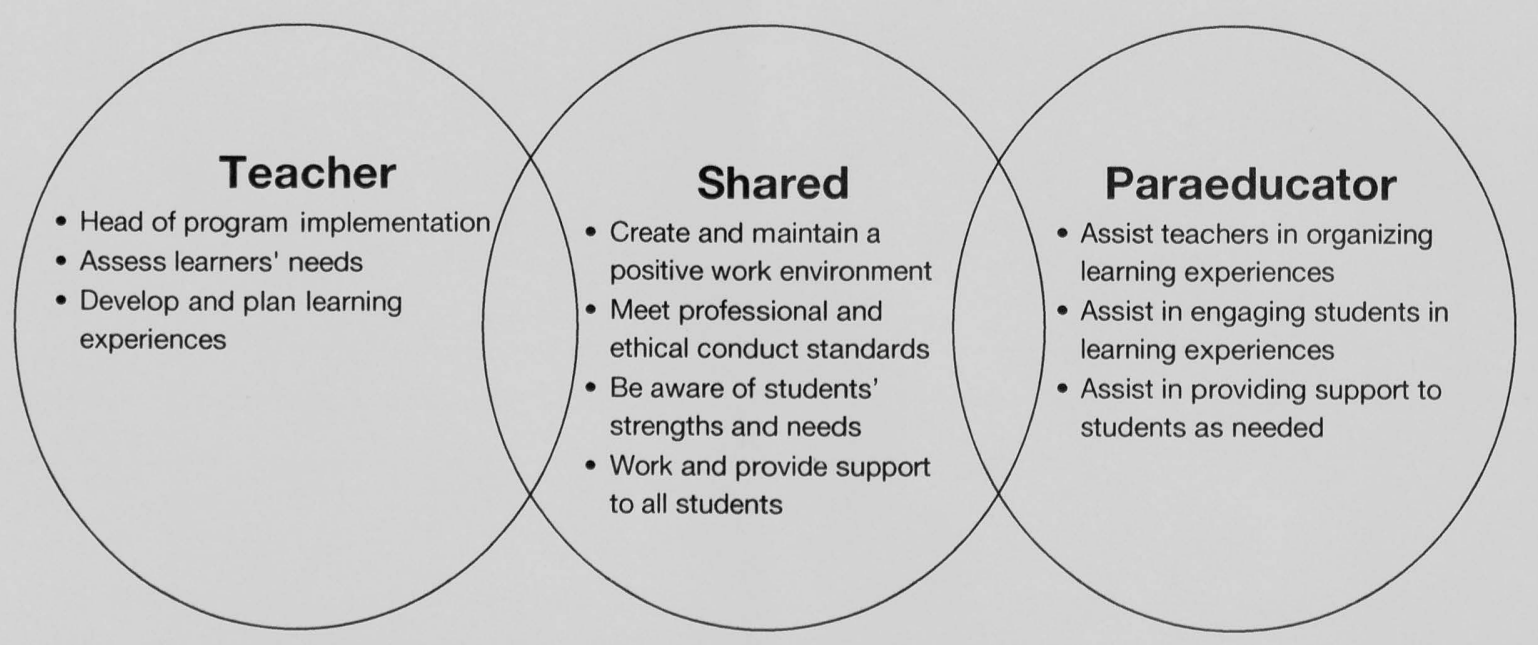

FIGURE 8.

Professional Duties and Responsibilities 


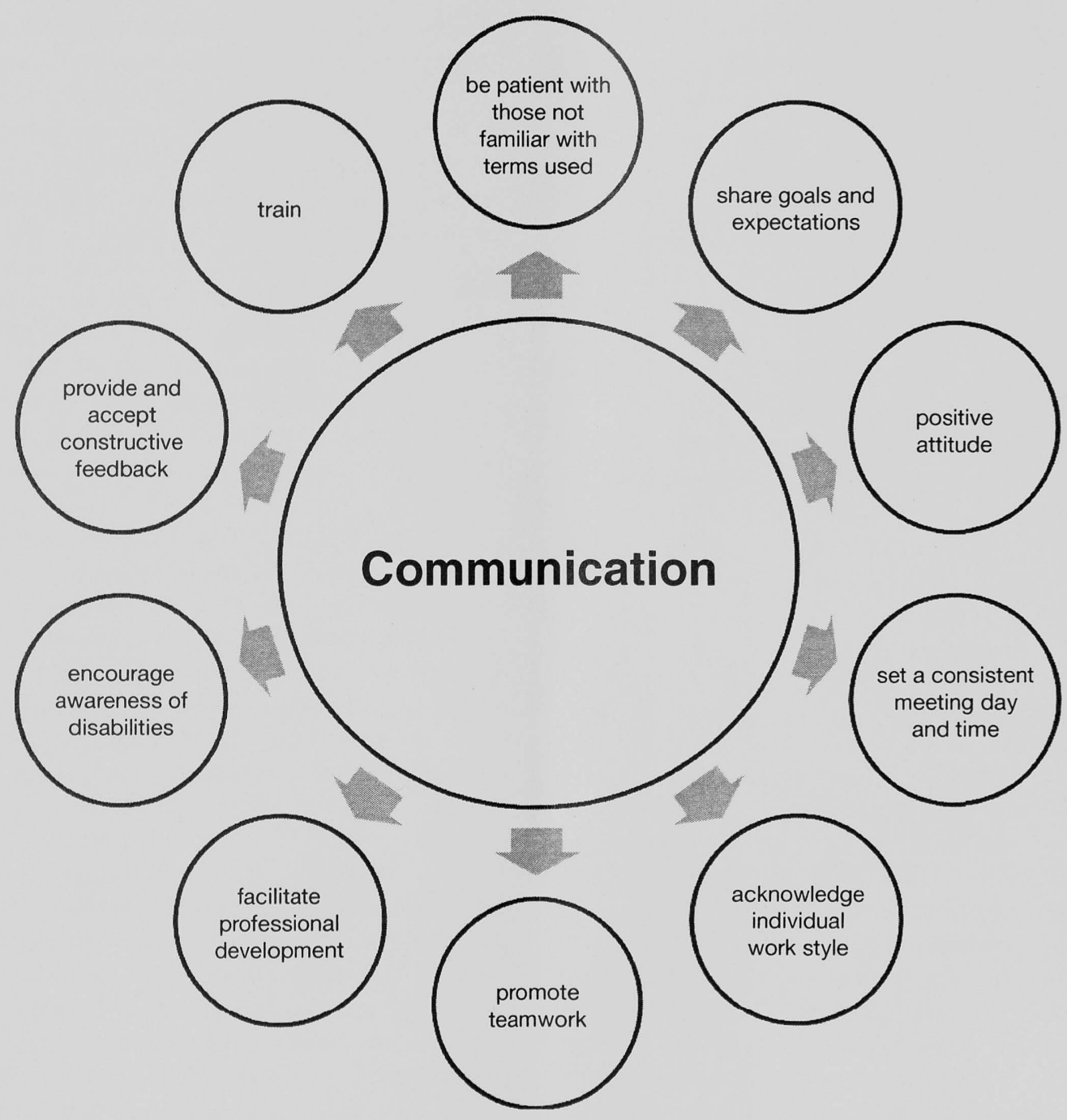

FIGURE 9.

Key to Effective Communication and Collaboration

Open lines of communication will encourage information sharing about students, improve planning and instruction, increase overall motivation for the job, and promote constructive feedback (Dierdorff \& Morgenson, 2007). While the CCSP was designed to improve overall communication between teacher-paraeducator teams, we provided a specific section to explicitly state important points that need to be addressed to enhance these opportunities (see Figure 4).

\section{Contact Information and Scheduled Meetings}

Successful collaboration requires frequent and open communication. Classroom communication should be based on encouraging each other, providing support and guidance when needed, and being open to discuss and brainstorm potential solutions. Open lines of communication in the classroom setting are important for teachers and paraeducators to address, respect, and acknowledge. However, this is often a challenge for teacher-paraeducator teams. There is a section on the CCSP to record contact information of team members and designate a primary contact person for the paraeducators (see Figure 4). This is specifically important because some paraeducators will often work in several different settings with general and special education teachers. In this case, paraeducators may find it difficult to know to whom they should bring questions or concerns. Specification on the CCSP will help clarify this. 


\section{Regular Meeting Times}

The importance of regularly scheduled meetings and sharing of information is acknowledged in the CCSP. Many teachers and paraeducators are dissatisfied by the limited time for meetings and communication (French, 1998). Planning time for communication with paraeducators can improve the overall work environment and should be made a priority in order to enhance communication and encourage common team goals. A space has been provided to identify a regularly scheduled weekly meeting time (see Figure 4). Building this meeting time into the school schedule facilitates communication among school teams and protects a time for a sit-down, consequently demonstrating that the whole team is valued. In addition, regular team meetings allow opportunities to provide feedback to paraeducators about their successes in their positions, discuss student progress, and even provide brief training.

\section{Providing Feedback}

Everyone wants to feel appreciated for his or her work. More important, everyone wants to feel valued as a member of a team. Paraeducators are no exception. Taking the time to acknowledge their work and thank them for what they do is invaluable. Praise and acknowledgement should come from those who work most closely with the paraeducator and genuinely know his or her work is appreciated (Carnahan, Williamson, Clarke, \& Sorensen, 2009; Giangreco \& Doyle, 2002; Giangreco et al., 2001).

Some teachers find their supervisory role quite difficult and struggle to communicate job performance evaluation. Observational evaluations involve subjectivity on part of the evaluators (Dierdorff \& Morgeson, 2009). Unless performance expectations are clearly outlined, evaluations can be quite subjective and vary by each rater. Constructive feedback on performance is a valuable component of effective communication with paraeducators. Teachers should actively supervise paraeducators and discuss the strengths and needs of each paraeducator's performance throughout the school year (National Joint Committee on Learning Disabilities, 1999; Trautman, 2004). Early identification and communication of areas in need of improvement can allow teachers to provide paraeducators with training and other opportunities for professional development.

\section{Confidentiality}

The CCSP also provides a section on confidentiality (see Figure 4). This section was added to facilitate consideration and conversations about the role of the paraeducator in communicating information about students. This section can easily be modified to fit particular needs and policies of schools. Paraeducators are in a unique situation. They interact with faculty and staff across the school, parents, and bus drivers. They are often the primary point of contact when people have questions about students. They have knowledge of sensitive information about students. Most paraeducators know little about guidelines on confidentiality. It is important to take the time to explain policies and lay out guidelines of when it is and is not appropriate to discuss student information.

\section{People-First Language}

In the same vein of ensuring professional communication among team members, we have provided a section on people-first language. This was included to remind teachers to discuss the importance of acknowledging the person first and his or her condition second with their paraeducators (see Figure 5). The use of people-first language is essential specifically because the use of certain descriptors to identify or describe a student can be overgeneralized, inaccurate, and stereotypical (Snow, 2010). At the same time, lack of training and acknowledgement of individual differences can create attitude and opportunity barriers between the adults working with students with exceptionalities (Snow, 2010), as well as between peers and students with exceptional needs (Causton-Theoharis \& Malmgrem, 2005).

\section{Work Style Preferences}

Understanding and acknowledging work style preferences and differences can also promote teamwork and collaboration and enhance overall communicative interactions within the classroom setting. Work style preferences are similar to learning styles, in that individuals favor particular means and methods to process information, complete tasks, and interact with others. Understanding vocational interests can also enhance lines of communication in the classroom setting. Van Iddekinge, Putka, and Campbell (2010) defined vocational interest as "relatively stable individual differences that influence behavior through preferences for certain work activities and work environment" (p. 2). This is supported by the theory of individual differences in job performance (e.g., Campbell, Gasser, \& Oswald, 1996), which outlines the relationship between motivation and performance. This theory suggests that an individual's performance of a task is influenced by his or her interest and motivation (e.g., Ackerman \& Heggestad, 1997; Sullivan \& Hansen, 2004). To enhance motivation and subsequent job performance, paraeducators need to be provided with the knowledge and support to complete tasks. Before teachers can provide such support, paraeducators should self-assess and reflect on their own work style preferences (French, 2003a; 2003b).

The CCSP provides a concise work style preference evaluation for both paraeducators and teachers to use during their introductory meeting (see Figure 5). The goal of the 
CCSP work style preference evaluation is to provide an opportunity to recognize preferences, similarities, and differences in work styles between teacher and paraeducator. By acknowledging specific work preferences, teachers and paraeducators can better recognize their differences, appreciate each other's strengths and weaknesses, and work toward providing the best services possible to their students. Knowledge and understanding of individual work styles increases tolerance and overall management of these differences within the classroom setting (French, 2003a). By clearly outlining, discussing, and understanding all members' work styles, a collaborative teamwork environment can be reinforced.

\section{Professional Development}

Paraeducators must be trained to deal with multiple expectations, skills, and challenges that can occur in the classroom setting. Unfortunately, the need for paraeducator training does not translate to formalized, enhanced school or district training opportunities. In fact, most available training programs lack specific focus on skills, knowledge, and professional development opportunities that meet the needs of the paraeducators' explicit roles and responsibilities. Paraeducators should be trained in evidence-based instructional strategies. This will allow them to feel more confident about their role in the classroom and, more important, provide effective strategies, instruction, and programming to the students. Unfortunately, most available training programs for paraeducators are focused on their student supervision roles (e.g., Cichoski Kelly, Backus, Giangreco, \& Sherman-Tucker, 2000; Doyle, 2001; Morgan \& Ashbaker, 2001; Pickett, Safrik, \& Echevarria, 1998; Pickett, Semrau, Faison, \& Formanek, 2006), evaluating and coaching (e.g., Harrison 1997; Morgan \& Ashbaker, 2001; Pickett et al., 2006), team building (e.g., Doyle 2001; Morgan \& Ashbaker, 2001; Pickett et al., 1998; Pickett et al., 2006), and communicating feedback (e.g., Cichoski Kelly et al., 2000; Harrison, 1997; Pickett et al., 2006; Wallace, Bernhardt, \& Utermarck, 1999). Although these training programs may be extremely useful for overall classroom management and supervision, paraeducators should receive training in evidence-based practices that will address the needs of the specific classroom setting, job requirements, and students to whom they will be assigned.

The CCSP provides a checklist of key areas of professional development training for those who work with exceptional learners (see Figure 6). The goal is to identify areas of interest for the paraeducators as well as areas that may be vital for the classroom setting. Some of the suggested areas within the CCSP are (a) understanding specific characteristics of student's disability, (b) instructional strategies, (c) behavior management, (d) health management, (e) data collection, and (e) materials adaptations - all common tasks and responsibilities paraeducators will undertake or support at some point in their careers. Additionally, the CCSP provides a section where specific district and school training opportunities can be identified. The goal is to compile important training opportunities that will not only enhance knowledge of those involved but also reinforce collaborative teamwork.

\section{COMMON PROBLEMS: MANAGING THE BUMPS IN THE ROAD}

Even with the best communication and preparation, there is no free ride to collaboration in the classroom setting. When teams work together there are always "bumps in the road." Effective teams are able to navigate these challenges and work through difficulties with a commitment to providing a supportive and positive educational environment for the students. Below, we present common challenges experienced by teachers and paraeducators and offer possible solutions that focus on respect and communication.

"Our classroom paraeducator comes in late and is often not where I need her to be in the school." - Supervising Teacher

Ask your paraeducator why she is late in the morning. Take time to review the schedule in the CCSP with the paraeducator. Let her know how important it is for her to be on time in the morning and in her assigned area in the school so that students are fully supported.

"We have two paraeducators working in our program. They are very close and I often find them talking in the hallway about students." - Supervising Teacher

Remind the paraeducators about confidentiality of information and review the guidelines in the CCSP. Let them know the risks involved in discussing sensitive information in public places as well as the importance of respecting students' privacy.

"I feel like the paraeducators on my team aren't doing enough. I know I choose to do the tasks myself, but it is because it takes me more time to train them than it does to just do things myself." - Supervising Teacher

Revisit the roles and responsibilities you outlined in the CCSP. You may need to revise them based on adjustments in your program, addition of students, and changes in student needs. After you have considered the needs in your classroom, meet with the paraeducators and reallocate responsibilities. Take the time to provide training to paraeducators in needed skills. Time spent on training can benefit 
your students, enhance the knowledge and skills of paraeducators, and free you up to provide support to more students.

\section{"You say we should train paraeducators, but our district doesn't provide funds or time for paraeducator training. What can I do?" - Supervising Teacher}

It is unfortunate, but many school districts have very limited funding for paraeducator training. Training falls to teachers, and there is often little to no time for training because of limited work hours for paraeducators. Teacherparaeducator teams need to be creative and use flexible planning to identify time for training. Sessions before or after school, during planning days, or even during student interaction time can be effective. Instructing paraeducators about tasks and providing training-while-doing can give paraeducators needed skills. For example, a teacher training a paraeducator in data collection may first explain how to use a data collection form, then have the paraeducator watch her complete the form while working with a student, and, finally, monitor and provide feedback to the paraeducator as he or she takes data.

Lack of funding for off-site training should not impede training. There are several free online training supports available to assist in providing training in core practices for working with students with disabilities (e.g., The Iris Center, www.iris.peabody.vanderbilt.edu; the Council for Exceptional Children Learning Center, cec.sclivelearningcenter. com; Special Education Institute www.specialeducationinstitute.com). Teachers can set aside time during the school day for paraeducators to explore these online training supports and then check with them to ensure full understanding of the concepts.

\section{"I've told the paraeducator in our program how to manage my students' behavior, but she thinks her way is better." - Supervising Teacher}

It is not uncommon for there to be a disconnect between the paraeducator's beliefs about managing behavior and strategies the teacher would like used in the classroom. Paraeducators often rely on their personal practices as parents or in childcare and, naturally, rely on those experiences in the school setting. It is the teacher's responsibility to ensure that adequate training be provided to the paraeducator. Many evidence-based behavior management principles may seem counterintuitive and foreign to those who are not trained in behavioral methods. Take the time to explain why these methods are necessary. Provide examples and explain why you do what you do when managing behavior. Also keep in mind that you are the supervisor and the paraeducator should comply with the skills and expectations you set out for your classroom and program.
"I don't feel like the teacher cares about my ideas. I know the students better than she does because I'm with them all day, but she never asks me what I think." - Paraeducator

During meeting times, teachers should ask paraeducators to share their experiences with the students, and they should be open and respectful of their ideas and thoughts about student needs. Teachers should encourage paraeducators to communicate their thoughts but also be willing to explain why they have chosen to use particular methods with students. They can use this opportunity to train and provide paraeducators with an educational experience of instructional and behavioral practices.

"This teacher is making me do much more and different things than the last teacher I worked with. I'm frustrated and uncomfortable." - Paraeducator

The supervising teacher should never assume that a paraeducator knows how to do a certain skill or task and should always ask the paraeducator if he or she feels comfortable with and understands the task to be completed. However, paraeducators should feel comfortable asking for help and extra training. At the same time, teachers should let paraeducators know of their willingness to help by providing the training needed. Laying the groundwork by completing the CCSP when a paraeducator begins his or her position can help pave the way for open and honest communication and a feeling of safety in asking questions.

"I don't agree with what my supervising teacher is doing with the students. How can I talk to her about this?" Paraeducator

Paraeducators should be encouraged to ask questions about selected instructional and interventional procedures and methods. Teachers should not immediately take this as an attack or "second-guessing" of the strategies. In order for communication to be effective, all members of the team should be willing to ask and answer questions in a respectful manner. Ultimately, though, the supervising teacher makes the final decision regarding instructional procedures.

\section{FINAL THOUGHTS}

Paraeducators play a valuable role in the educational experiences of students with exceptionalities. Their efforts in assisting in tasks such as student self-care, adaptation of materials, modification of assignments, and data collection allow teachers to provide more comprehensive and meaningful instruction to a wider range of students. The number of paraeducators in schools will continue to rise as provision of special education services becomes ever more inclusive. 
Consequently, it is essential that paraeducators become adequately prepared for their positions, as this will have an immediate and long-term effect on their interactions with students with exceptionalities (Causton-Theoharis \& Malmgrem, 2005).

The responsibility for using evidence-based practices in special education does not lie only with teachers but also with paraeducators. Paraeducators often do not receive a clear, thoughtful description of their roles and responsibilities or the training needed to fully meet these expectations by using evidence-based practices. Because of the increased dependence on paraeducators to work with students with exceptionalities, the goal should be for teachers to support paraeducators in their training opportunities and help them move towards meeting all the Council for Exceptional Children (CEC) performance-based standards. These standards will provide paraeducators the opportunity to maintain and enhance the knowledge and skills necessary to meet the needs of the students and the setting. In addition, knowledge and use of the CEC standards can help identify potential professional development opportunities for both teachers and paraeducators (Crutchfield, 2003).

Paraeducators need to be familiar with their roles and responsibilities, understand the context in which they are working, and recognize their roles as members of a team. Paraeducators also need the opportunity to discuss job expectations and express their satisfaction or concerns (May \& Marozas, 1981) with their supervising teacher, administrator, or both. This can be a challenging task if the classroom or school setting is not based on a collaborative team-based approach. By using a structured plan such as the CCSP, teachers and administrators have a means of actively engaging paraeducators as team members. The CCSP also provides the opportunity to identify potential training needs to enhance overall procedures in the classroom setting and facilitate communication among administrators, teachers, and paraeducators. As a result, the CCSP assists teams in creating a motivating, supportive, and knowledge-seeking environment for those who work with students with exceptional needs.

\section{REFERENCES}

Ackerman, P. L., \& Heggestad, E. D. (1997). Intelligence, personality, and interest: Evidence for overlapping traits. Psychological Bulletin, 121, 219-245. doi: 10.1037/0033-2909.121.2.219

Ashbaker, B. Y., \& Morgan, J. (2006). Paraprofessionals in the classroom. Boston: Pearson Education.

Bruner, C. (1991, April). Thinking collaboratively: Ten questions and answers to help policy makers improve children's services. Washington, DC: Education and Human Services Consortium.

Campbell, J. P., Gasser, M. B., \& Oswald, F. L. (1996). The substantive nature of job performance variability. In K. R. Murphy (Ed.),
Individual differences and behaviors in organizations (pp. 258299). Hillsdale, NJ: Erlbaum.

Carnahan, C. R., Williamson, P., Clarke, P., \& Sorensen, R. (2009). A systematic approach for supporting paraeducators in educational settings: A guide for teachers. Teaching Exceptional Children, 41, $34-43$.

Carroll, D. (2001). Considering paraeducators training, roles, and responsibilities. Teaching Exceptional Children, 34(2), 60-64.

Causton-Theoharis, J. N., \& Malmgren, K. W. (2005). Increasing peer interactions for students with severe disabilities via paraprofessional training. Exceptional Children, 71, 431-444.

Cichoski Kelly, E., Backus, L., Giangreco, M. F., \& Sherman-Tucker, P. (2000). Paraeducator entry-level training for supporting students with disabilities. Retrieved from ERIC database (ED471798).

Crutchfield, M. D. (2003). What do the CEC standards mean to me? Using the CEC standards to improve my practice. Teaching Exceptional Children, 35(6), 40-45.

Dierdorff, E. C., \& Morgenson, F. P. (2007). Consensus in work role requirements: The influence of discrete occupational contacts on role expectations. Journal of Applied Psychology, 92, 1228-1241.

Dierdorff, E. C., \& Morgenson, F. P. (2009). Effects of descriptors specificity and observability on incumbent work analysis ratings. Personnel Psychology, 62, 601-628.

Downing, J., Ryndak, D., \& Clark, D. (2000). Paraeducators in inclusive classrooms: Their own perspective. Remedial and Special Education, 21, 171-181.

Doyle, M. B. (2008). The paraprofessional's guide to the inclusive classroom: Working as a team (3rd ed.). Baltimore: Brookes.

Drecktrah, M. E. (2000). Preservice teachers' preparation to work with paraeducators. Teacher Education and Special Education, 23, 157-164.

French, N. K. (1998). Working together: Resource teachers and paraeducators. Remedial and Special Education, 19, 357-368.

French, N. K. (1999a). Paraeducators and teachers: Shifting roles. Teaching Exceptional Children, 32, 69-73.

French, N. K. (1999b). Pareducators: Who are they and what do they do? Teaching Exceptional Children, 32, 65-69.

French, N. K. (2003a). Management of paraeducatos. In A. L. Pickett and K. Gerlach, Supervising paraeducators in educational settings: A team approach (pp. 97-172, 2nd ed.). Austin, TX: Pro-Ed.

French, N. K. (2003b). Paraeducators in special education programs. Focus on Exceptional Children, 36(2), 1-16.

Giangreco, M. F., Broer, S. M., \& Edelman, S. W. (2002). The tip of the iceberg: Deterring whether paraprofessional support is needed for students with disabilities in general education settings. The Journal of the Association for Persons with Severe Handicaps, 24 , 280-290.

Giangreco, M. F., \& Doyle, M. B. (2002). Students with disabilities and paraprofessional supports: Benefits, balance, and band-aids. Focus on Exceptional Children, 34, 1-12.

Giangreco, M. F., Edelman, S. W., \& Broer, S. M. (2001). Paraprofessional support of students with disabilities: Literature from the past decade. Exceptional Children, 68, 45-63.

Giangreco, M. F., Edelman, S. W., \& Broer, S. M. (2003). Schoolwide planning to improve paraeducator supports. Exceptional Children, $70,63-79$.

Harrison, S. (1997). Career development for non-traditional community college students as special education paraprofessionals: Final report. Retrieved from ERIC database. ED415647. 
Hilton, A., \& Gerlach, K. (1997). Employment, preparation and management of paraeducators: Challenges to appropriate service for students with developmental disabilities. Education and Teaching in Mental Retardation and Developmental Disabilities, 71-76.

Individuals with Disabilities Education Improvement Act of 2004, 20 U. S. C. $\$ \S 1400$ et seq. (2004).

Malmgren, K. W., Causton-Theoharis, J. N., \& Trezek, B. J. (2005). Increasing peer interactions for students with behavioral disorders via paraprofessional training. Behavioral Disorders, 31, 95-106.

Marks, S. U., Schrader, C., \& Levine, M. (1999). Paraeducator experiences in inclusive settings: Helping, hovering, or holding their own? Exceptional Children, 65, 315-328.

May, D. C., \& Marozas, D. S. (1981). The role of the paraprofessional in educational programs for the severely handicapped. Education and Training of the Mentally Retarded, 16, 228-231.

Morgan, J., \& Ashbaker, B. Y. (2001). A teacher's guide to working with paraeducators and other classroom aides. Alexandria, VA: Association for Supervision and Curriculum Development.

Morgan J., Ashbaker, B., \& Forbush, D. (1998). Strengthening the teaching team: Teachers and paraprofessionals learning together. Support for Learning, 13, 115-117.

National Joint Committee on Learning Disabilities. (1999). Learning disabilities: Use of paraprofessionals. Learning Disability Quarterly, 22, 23-30.

Orwell, G. (1981). Politics and English language. In A collection of essays (pp. 156-170). Orlando, FL: Harvest.

Pickett, A. L., Likins, M., \& Wallace, T. (2003). The employment and preparation of paraeducators: The state-of-the-art-2003. National Resource Center for Paraeducators. Retrieved from http://www. nrcpara.org/files/state-of-the-art.pdf

Pickett, A. L., Safrik, L., \& Echevarria, J. (1998). A core curriculum \& training program to prepare paraeducators to work with learners who have limited English proficiency. Retrieved from ERIC database. (ED436873)

Pickett, A. L., Semrau, B., Faison, K., \& Formanek, J. (2006). A core curriculum and training program to prepare paraeducators to work in center-and home-based programs for young children with disabilities from birth to age 5 (3rd ed.). New York: Christopher Phillips.
Schmidt, K., Grenough, R., \& Nelson, S. R. (2002). Designing state and local policies for the professional development of instructional paraeducators. Northwest Regional Education Laboratory. Retrieved from http://www.eric.ed.giv/PDFS/ED476693.pdf

Snow, K. (2010). To ensure inclusion, freedom, and respect for all, it's time to embrace people first language. Retrieved from Disability is Natural E-Newsletter http://www.acdd.org/wp-content/uploads/ 2011/01/People_First_Language.pdf

Sullivan, B. A., \& Hansen, J. C. (2004). Mapping associations between interest and personality: Towards a conceptual understanding of individual differences in vocational behavior. Journal of Counseling Psychology, 51, 287-298.

Trautman, M. L. (2004). Preparing and managing paraprofessionals. Intervention in School and Clinic, 39, 131-138.

Van Iddekinge, C. H., Putka, D. J., \& Campbell, J. P. (2010). Reconsidering vocational interest for personnel selection: The validity of an interest-based selection test in relation to job knowledge, job performance, and continuance intentions. Journal of Applied Psychology, 10, 1-21.

U.S. Department of Labor. (2010). Occupational outlook handbook, 2010-11 edition, teacher assistants. Retrieved from http://www/ bls.gov/oco/ocos 153 .htm

Wadsworth, D., \& Knight, D. (1996). Paraprofessionals: The bridge to successful full inclusion. Intervention in School \& Clinic, 31, 166-172.

Wallace, T., Bernhardt, J., \& Utermarck, J. (1999). Minnesota paraprofessional guide. Retrieved from ERIC. (ED438638)

Wallace, T., Shin, J., Bartholomay, T., \& Stahl, G. H., (2001). Knowledge and skills for teachers supervising the work of parprofessionals. Exceptional Children, 67, 520-533.

\section{PERMISSIONS AND COPYRIGHT}

All rights are reserved. No part of this publication may be reproduced, photocopied, faxed, stored in a retrieval system, or transmitted in any form or by any means, electronic, mechanical, recording or otherwise, without the prior written permission of the publisher.
Back issues are available for sale. Reproduction requires permission and payment of fees. It is illegal and a violation of federal copyright law to reproduce this publication without permission. Direct all inquiries to the permissions editor. 